\title{
Functional Activity of Some Growth Regulators on Yield Components and Endogenous Hormones of Cowpea Plants (Vigna sinensis L.)
}

\author{
Salem M. Al-Amri \\ Department of Biological Sciences, College of Science and Art, Shaqra University, Shaqraa, Riyadh, KSA \\ Email: phd1618@hotmail.com
}

How to cite this paper: Al-Amri, S.M. (2018) Functional Activity of Some Growth Regulators on Yield Components and Endogenous Hormones of Cowpea Plants (Vigna sinensis L.). Agricultural Sciences, 9, 1229-1239.

https://doi.org/10.4236/as.2018.910086

Received: July 7, 2018

Accepted: September 27, 2018

Published: September 30, 2018

Copyright $\odot 2018$ by author and Scientific Research Publishing Inc. This work is licensed under the Creative Commons Attribution International License (CC BY 4.0).

http://creativecommons.org/licenses/by/4.0/

\section{Open Access}

\begin{abstract}
The effect of seed presoaking with different concentrations of growth bio-regulators (indole acetic acid, gibberellic acid and kinetin) on productivity and some biochemical and physiological aspects of yielded seeds of cowpea (Vigna sinensis L.) was investigated. Generally, application of growth regulators stimulated yield and yield quality of cowpea plants as compared to control plants through inducing a massive increase in number of pods/plants, seed biomass, pod length and number of seeds. In addition, results of this study showed that these growth regulators increased protein content and total soluble sugars in cowpea yielded seeds. Finally, it is evident from the present data that application of kinetin appeared to be the most effective hormone in stimulated productivity endogenous hormones and biochemical aspects in yielded seeds of cowpea plants.
\end{abstract}

\section{Keywords}

Bio-Regulator Hormones, Cowpea Plants, Yield Components, Kinetin, Auxins

\section{Introduction}

Cowpea (Vigna sinensis L.) is one of the most popular and widely consumed vegetable crops all over the world, and high-quality yield is an essential prerequisite for its economic success in the Saudi Arabia. Cowpea is the most economically important indigenous legume crop [1] [2]. Cowpea seed was used in nutritious component in the human diet, as well as a nutritious livestock feed. Cowpea seed is rich in the amino acids, tryptophan and lysine, compared to other cereal grains; but it is deficient in methionine and cystine as compared with animal proteins [3]. In this connection, cowpea seed is valued as a nutri- 
tional supplement to cereals and an extender of animal proteins [4].

Application of plant growth regulators to enhance growth and yield components of plants were studied [5] [6] [7]. In this connection, exogenous application of gibberellic acid highly stimulated the growth of Pisum sativum [2] [8]. [9] reported that the foliar application of gibberellic acid at 50 and $75 \mathrm{ppm}$ enhanced the photosynthetic activity of Gossypium arborium and consequently the total photosynthetic metabolites, total soluble sugars and protein contents. In addition foliar application of gibberellic acid at 50 or $100 \mathrm{ppm}$ increased seed yield, pod yield and harvest index of Vicia faba plants [4] [10].

Farghali and Hussein (1994) [11] and Prajapati et al. (2015) [12] reported that presoaking of carrot roots in IAA at $100 \mathrm{ppm}$ stimulated seed yield and harvest index. Furthermore, [13] using soybean and Sesamum plants found that soaking of soybean seeds in IAA at different concentrations (50, 75 and $100 \mathrm{ppm}$ ) increased the growth and yield of treated plants. Moreover, [7] [14] reported that application of IAA increased endogenous auxin and gibberellin activities at flowering stage.

Foliar application of kinetin at 100 and 200 ppm caused a massive increase in shoot fresh weight of wheat plants [15] [16] [17]. Kinetin stimulated lateral buds, plant height, chlorophyll content, leaf area of Helioanthus annus [18] [19]. Moreover, [20] [21] reported that the application of kinetin significantly increased the fresh and dry weight of wheat plants. In addition, [22] [23] showed that soaking soybean seeds in some growth hormones significantly increased total protein and oil content in yielded seeds as compared to untreated plants. The present work was planned to investigate the effect of growth bioregulators on yield and yield attributes of cowpea plants. Total protein and total soluble sugars in yielded seeds were also determined.

\section{Materials and Methods}

\subsection{Plant and Growth Conditions}

Seeds of cowpea (Vigna sinensis L.) were obtained from Supermarket of Agricultural Research Center, Saudi Arabia. The selected seeds were surface sterilized in $5 \%$ sodium hypochlorite for $10 \mathrm{~min}$, subsequently washed thoroughly with deionized water. The uniformed sterilized seeds (approximately one kilogram) were been divided into ten sets. Seeds of the $1^{\text {st }}$ set were soaked in deionized water to serve as control, the $2^{\text {nd }}, 3^{\text {rd }}$ and $4^{\text {th }}$ sets were soaked in different concentrations $(25,50$ or $75 \mathrm{ppm})$ of gibberellic acid $\left(\mathrm{GA}_{3}\right)$ for three hours respectively. The $5^{\text {th }}, 6^{\text {th }}$ and $7^{\text {th }}$ sets were soaked in different concentrations $(50,100$ or 150 $\mathrm{ppm}$ ) of indole acetic acid (IAA) for three hours respectively. The $8^{\text {th }}, 9^{\text {th }}$ and $10^{\text {th }}$ sets were soaked in different concentrations $(25,50$ or $75 \mathrm{ppm})$ of kinetin for three hours respectively, then washed with distilled water. All these treated seeds were left to germinate for 5 days on a moistened filter paper in dark at $25^{\circ} \mathrm{C}$. Uniform germinated seedlings were sown in plastic pots $(30 \mathrm{~cm}$ in diameter $)$ 
containing equal amount of soil (Sand and Clay 2:1) and left to grow in a greenhouse under controlled conditions in a randomized complete block design at the research experimental farm of the Facility of Science, King Saud University, Riyadh. Soil characteristics used in this study were $\mathrm{pH} 7.18$, electrical conductivity $1.81 \mathrm{ds} \mathrm{cm}^{-1}$, total organic matter $0.64 \%$, total $\mathrm{N}: 98.0 \mathrm{mg} \mathrm{kg}^{-1}$, total P: 18.6 $\mathrm{mg} \mathrm{kg}{ }^{-1}, \mathrm{Mg}: 118 \mathrm{mg} \mathrm{kg}^{-1} ; \mathrm{K}: 144 \mathrm{mg} \mathrm{kg}^{-1}$, and $\mathrm{Ca}^{+2}: 565 \mathrm{mg} \mathrm{kg}^{-1}$. All plants were watered as needed with tap water to maintain soil moisture near field capacity $(75 \%-80 \%)$ and fed once weekly with $35 \mathrm{~g}$ potassium $/ \mathrm{m}^{2}$ as superphosphate and $35 \mathrm{~g}$ nitrogen $/ \mathrm{m}^{2}$ as potassium nitrate as a nutritive solution. Twelve weeks after sowing, six plants per each treatment were harvested.

\subsection{Analysis of Yield and Yield Components}

Pod length, number of pods, number of seeds and 100-seeds weight of each treatment of cowpea plants were determined.

Harvest index $=$ Grain yield/Above ground dry matter $\times 100$ (Beadle, 1993).

Relative grain yield $=$ Yield in treated plant/Yield in untreated $\times 100$ (Beadle, 1993) [24].

\subsection{Estimation of Total Soluble Sugars and Total Soluble Protein in Yielded Seeds}

Total soluble sugars (TSS) were determined after the extraction of dry seeds of each treatment in $10 \mathrm{ml}$ of $80 \%(\mathrm{v} / \mathrm{v})$ ethanol at room temperature with periodic shaking for 12 hours. TSS were determined using modifications of the method of Abdel-Fattah et al. (2002) [25].

Total protein in extracted seed yield of each treatment was determined by the method of Bradford (1976) [26]. 100 mg of Coomassie Beillient blue G-250 was mixed with $50 \mathrm{ml}$ of ethanol (95\%) and $100 \mathrm{ml}$ of phosphoric acid (85\%), the combined volume was diluted to 1 liter and served as protein reagent. $50 \mu$ of sample was mixed with $5 \mathrm{ml}$ of protein reagent plus $1 \mathrm{ml}$ of phosphate buffer (0.1 M, pH 7.2). The absorbance was recorded after $2 \mathrm{~min}$. at $595 \mathrm{~nm}$ against the blank.

\subsection{Determination of Endogenous Hormones}

A high performance liquid chromatographic (HPLC) method was developed to determine the four endogenous hormones including indole-3-acetic acid (IAA), abscisic acid (ABA), gibberellic acid $\left(\mathrm{GA}_{3}\right)$, and kinetin in cowpea seeds. Methanol was chosen as the extraction solvent for the optimum conditions of separation. Then, the macerated extract was extracted by petroleum ether and ethyl acetate, and then purified with the Sep-Pak C18 column. The chromatographic conditions were as follows: Eclipse XDB-C18 reversed phase column (300 mm x $5.6 \mathrm{~mm}, 5 \mathrm{microm})$, the flow rate of $1 \mathrm{~mL} / \mathrm{min}$, the injection volume of $10 \mathrm{mi}$ croL, and the detection wavelength of $240 \mathrm{~nm}$ were used for the separation of endogenous hormones. Methanol (A) and acetic acid aqueous solution ( $\mathrm{pH} 3.6$ ) (B) were used as the mobile phases with the linear gradient set as follows: $0-7$ 
$\min 20 \%$ A, 7 - $10 \min 20 \%$ A-28\% A, $10-17 \min 28 \%$ A, $17-19 \min 28 \%$ A-40\% A, 19 - 35 min 40\% A. Extraction and purification was performance according the method of Terry et al. (1982) [27].

\subsection{Statistical Analysis}

All data were subjected to statistical analysis using one-way analysis of variance (ANOVA). Using Duncan's multiple range tests, means were separated by the least significant difference (LSD, $P \leq 0.05$ ) method using the Costat software (Cohort, Berkeley, Calif).

\section{Results}

\subsection{Yield and Yield Components}

Comparing to control plants, cowpea seeds presoaking in different doses of IAA (50, 100 and $150 \mathrm{ppm}$ ) significantly increased length of pod, pods number, pod weight, number of seeds, 100-seeds weight, relative seed yield and harvest index of cowpea plants (Table 1). Furthermore, the results indicated that the increase in the different yield components was more pronounced with the increase in concentration of IAA except for relative seed yield where no significant differences among the concentrations of IAA were observed.

Concerning the effect of $\mathrm{GA}_{3}$, the results reported in Table 2 showed that the application of $\mathrm{GA}_{3}$ at 25, 50 and $75 \mathrm{ppm}$ induced significant increase in all parameters of yield and yield components when comparing to the control untreated cowpea plants. On contrary, no significance differences were observed in most yield components between plants treated with 50 and 75 ppm of $\mathrm{GA}_{3}$.

Seed presoaked in kinetin at all concentrations (25, 50 and $75 \mathrm{ppm}$ ) significantly increased yield and yield parameters of cowpea plants by increasing pod length, number of pods, pod weight, 100-seeds weight and harvest index (Table 3 ). The increasing in the concentrations of kinetin, in general, increases the values

Table 1. Effect of different concentrations of indole acetic acid (IAA) on yield and yield components of cowpea plants.

\begin{tabular}{ccccc}
\hline \multirow{2}{*}{ Parameters } & \multicolumn{4}{c}{ Indole acetic acid (ppm) } \\
\cline { 2 - 5 } & Control & 50 & 100 & 150 \\
\hline Pod length $(\mathrm{cm})$ & $8.2 \mathrm{c}$ & $10.5 \mathrm{~b}$ & $12.0 \mathrm{a}$ & $12.8 \mathrm{a}$ \\
Weight of pod $(\mathrm{g})$ & $0.95 \mathrm{c}$ & $1.10 \mathrm{bc}$ & $1.89 \mathrm{~b}$ & $2.94 \mathrm{a}$ \\
Number of pods/plant & $2.93 \mathrm{bc}$ & $3.55 \mathrm{~b}$ & $3.87 \mathrm{~b}$ & $4.98 \mathrm{a}$ \\
Number of seeds/pod & $4.51 \mathrm{c}$ & $6.11 \mathrm{ab}$ & $7.34 \mathrm{a}$ & $8.01 \mathrm{a}$ \\
Harvest index $(\%)$ & $200 \mathrm{c}$ & $410 \mathrm{~b}$ & $450 \mathrm{a}$ & $455 \mathrm{a}$ \\
100 seeds weight $(\mathrm{g})$ & $9.21 \mathrm{~b}$ & $10.5 \mathrm{ab}$ & $11.25 \mathrm{ab}$ & $12.50 \mathrm{a}$ \\
Relative seed yield $(\%)$ & $1.14 \mathrm{~b}$ & $2.90 \mathrm{a}$ & $3.11 \mathrm{a}$ & $3.20 \mathrm{a}$ \\
\hline
\end{tabular}

${ }^{*}$ Values in each row followed by the same letter(s) are not significantly different at $P \leq 0.05$ (Duncan's multiple range test). Each value represents the mean of six replicates. 
Table 2. Effect of different concentrations of gibberellic acid $\left(\mathrm{GA}_{3}\right)$ on yield and yield components of cowpea plants.

\begin{tabular}{ccccc}
\hline & \multicolumn{4}{c}{ Gibberellic acid (ppm) } \\
\cline { 2 - 5 } Parameters & Control & 25 & 50 & 75 \\
\hline Pod length $(\mathrm{cm})$ & $8.97 \mathrm{~b}$ & $11.22 \mathrm{ab}$ & $12.0 \mathrm{a}$ & $12.50 \mathrm{a}$ \\
Weight of pod $(\mathrm{g})$ & $0.73 \mathrm{~b}$ & $1.11 \mathrm{ab}$ & $1.54 \mathrm{a}$ & $1.74 \mathrm{a}$ \\
Number of pods/plant & $1.93 \mathrm{bc}$ & $2.55 \mathrm{~b}$ & $3.01 \mathrm{~b}$ & $3.98 \mathrm{a}$ \\
Number of seeds/pod & $3.51 \mathrm{c}$ & $6.33 \mathrm{~b}$ & $8.24 \mathrm{a}$ & $9.11 \mathrm{a}$ \\
Harvest index (\%) & $190 \mathrm{c}$ & $310 \mathrm{~b}$ & $350 \mathrm{~b}$ & $477 \mathrm{a}$ \\
100 seeds weight (g) & $9.31 \mathrm{~b}$ & $11.80 \mathrm{ab}$ & $12.26 \mathrm{ab}$ & $13.88 \mathrm{a}$ \\
Relative seed yield $(\%)$ & $1.25 \mathrm{c}$ & $3.44 \mathrm{~b}$ & $3.91 \mathrm{ab}$ & $4.20 \mathrm{a}$ \\
\hline
\end{tabular}

See footnote in Table 1.

Table 3. Effect of different concentrations of kinetin on yield and yield components of cowpea plants.

\begin{tabular}{ccccc}
\hline & \multicolumn{4}{c}{ Kinetin (ppm) } \\
Parameters & Control & 25 & 50 & 75 \\
\cline { 2 - 4 } & $8.25 \mathrm{c}$ & $12.56 \mathrm{~b}$ & $13.00 \mathrm{a}$ & $14.18 \mathrm{a}$ \\
Pod length (cm) & $0.90 \mathrm{c}$ & $1.66 \mathrm{bc}$ & $1.99 \mathrm{~b}$ & $2.98 \mathrm{a}$ \\
Weight of pod (g) & $1.93 \mathrm{c}$ & $4.05 \mathrm{~b}$ & $5.88 \mathrm{~b}$ & $6.77 \mathrm{a}$ \\
Number of pods/plant & $4.11 \mathrm{c}$ & $6.81 \mathrm{~b}$ & $7.99 \mathrm{ab}$ & $10.50 \mathrm{a}$ \\
Number of seeds/pod & $199 \mathrm{~d}$ & $520 \mathrm{c}$ & $640 \mathrm{~b}$ & $785 \mathrm{a}$ \\
Harvest index (\%) & $9.11 \mathrm{c}$ & $11.54 \mathrm{bc}$ & $12.28 \mathrm{~b}$ & $14.90 \mathrm{a}$ \\
100 seeds weight (g) & $1.11 \mathrm{c}$ & $3.55 \mathrm{~b}$ & $4.98 \mathrm{~b}$ & $5.55 \mathrm{a}$ \\
\hline
\end{tabular}

See footnote in Table 1.

of the different determined yield components of cowpea plants.

Based on the obtained results here, kinetin at the different used concentrations is the powerful growth regulator for improving the productivity of cowpea plants when compared with the other growth regulator treatments (IAA or $\mathrm{GA}_{3}$ ). Thus, the higher values for the different yield components were observed in the plant treated with different concentrations of kinetin.

\subsection{Total Soluble Sugars and Protein}

As compared to control, treatment with growth regulators (IAA and kinetin) significantly increased total soluble sugars in the yielded seeds of cowpea plants (Table 4). No significant differences in total soluble sugars were observed in yielded seeds of cowpea plants treated with different concentrations of $\mathrm{GA}_{3}$. The magnitude increase in total soluble sugars was more pronounced in response to the highest concentrations of each growth regulators used.

Application of growth regulators increased the accumulation of protein in the 
Table 4. Effect of seed presoaking in different concentrations of IAA, GA 3 and kinetin $(\mathrm{ppm})$ on protein content $\left(\mu \mathrm{g} \cdot \mathrm{g}^{-1} \mathrm{dwt}\right)$ and total soluble sugars $\left(\mu \mathrm{g} \cdot \mathrm{g}^{-1} \mathrm{dwt}\right)$ in yielded seeds of cowpea plants.

\begin{tabular}{ccc}
\hline \multirow{2}{*}{ Treatments } & \multicolumn{2}{c}{ Parameters } \\
\cline { 2 - 3 } Control & Protein & Total soluble sugars \\
\hline$\underline{\text { IAA }}$ & $950 \mathrm{e}$ & $480 \mathrm{~d}$ \\
50 & & \\
100 & $1050 \mathrm{e}$ & $610 \mathrm{~cd}$ \\
150 & $1410 \mathrm{~cd}$ & $835 \mathrm{bc}$ \\
$\underline{\text { GA }} \underline{3}$ & $1580 \mathrm{c}$ & $892 \mathrm{~b}$ \\
25 & & $720 \mathrm{c}$ \\
50 & $1320 \mathrm{~d}$ & $725 \mathrm{c}$ \\
75 & $1560 \mathrm{c}$ & $740 \mathrm{c}$ \\
$\underline{\text { Kinetin }}$ & $1808 \mathrm{ab}$ & \\
25 & & $922 \mathrm{~b}$ \\
50 & $1530 \mathrm{c}$ & $1038 \mathrm{~b}$ \\
75 & $1710 \mathrm{~b}$ & $1316 \mathrm{a}$ \\
\hline
\end{tabular}

See footnote in Table 1.

yielded seeds of cowpea plants as compared to the control treatments (Table 4). Kinetin induced a massive increased in the protein content when compared with other growth regulator hormones used in this study.

\subsection{Endogenous Growth Regulators}

Results of the changes in the endogenous auxins, cytokinins, gibberellins and abscisic acid contents in the yielded seeds of cowpea plants in response to application with IAA, $\mathrm{GA}_{3}$ or kinetin were recorded in Table 5. Application with IAA, $\mathrm{GA}_{3}$ and kinetin induced a marked increase in the level of total auxins, gibberellins and cytokinins when compared to the control treatments. The increasing in the concentration of each growth regulator used increased the accumulation of endogenous level of the detected growth regulators (total auxins, gibberellins and cytokinins). On the other hand, the endogenous abscisic acid content in the yielded seeds of cowpea plants was significantly decreased as compared to control plants. In addition, kinetin at all concentrations induced the highest levels of total auxins, gibberellins and cytokinins and the lowest level of abscisic acid when compared to the corresponding level of other growth regulators used in the yielded seeds of cowpea plants.

\section{Discussion}

Three growth regulators were used in this study for improvement of some 
Table 5. Effect of different concentrations of IAA, GA 3 and kinetin (ppm) on endogenous hormones content $\left(\mu \mathrm{g} \cdot \mathrm{g}^{-1} \mathrm{fwt}\right)$ in yielded seeds of cowpea plants.

\begin{tabular}{ccccc}
\hline \multirow{2}{*}{ Treatments } & \multicolumn{3}{c}{ Parameters } \\
\cline { 2 - 5 } Control & IAA & $\mathrm{GA}_{3}$ & Cytokintin & Absisic acid \\
$\underline{\text { IAA }}$ & $220 \mathrm{~d}$ & $130 \mathrm{c}$ & $90 \mathrm{~d}$ & $180 \mathrm{a}$ \\
50 & & & & \\
100 & $410 \mathrm{~b}$ & $140 \mathrm{~b}$ & $105 \mathrm{c}$ & $160 \mathrm{~b}$ \\
150 & $557 \mathrm{a}$ & $147 \mathrm{~b}$ & $125 \mathrm{~b}$ & $155 \mathrm{~b}$ \\
$\underline{\text { GA }} \underline{30}$ & $584 \mathrm{a}$ & $156 \mathrm{~b}$ & $130 \mathrm{~b}$ & $140 \mathrm{c}$ \\
25 & & & & \\
50 & $250 \mathrm{c}$ & $135 \mathrm{~b}$ & $98 \mathrm{c}$ & $155 \mathrm{~b}$ \\
75 & $278 \mathrm{c}$ & $142 \mathrm{~b}$ & $110 \mathrm{c}$ & $130 \mathrm{~d}$ \\
$\underline{\text { Kinetin }}$ & $310 \mathrm{bc}$ & $150 \mathrm{~b}$ & $125 \mathrm{~b}$ & $114 \mathrm{ab}$ \\
25 & & & & \\
50 & $505 \mathrm{ab}$ & $150 \mathrm{~b}$ & $105 \mathrm{c}$ & $160 \mathrm{~b}$ \\
75 & $566 \mathrm{a}$ & $188 \mathrm{a}$ & $135 \mathrm{~b}$ & $143 \mathrm{c}$ \\
\hline
\end{tabular}

See footnote in Table 1.

physiological activities and productivity of cowpea plants. From the results, it was observed that seed presoaking in different concentrations of IAA, $\mathrm{GA}_{3}$ or kinetin appeared to increase the different yield parameters (pod weight, pod length number of pods, number of seeds/pod, 100-seeds weight and relative growth yield) of cowpea plants when comparing with untreated control plants. The increase in cowpea productivity is probably due to the increase in rate of transpiration, and translocation of photosynthates from leaves to developing seeds caused by hormone treatments [2] [7]. Furthermore, the enhancement of yield attributes in response to the growth regulators used in this study might be due to the stimulatory effect of these growth regulators on expansion of leaf area, pigment production and photosynthetic activity which in turn increased carbohydrates content in cowpea leaves and consequently increased in yield quality of cowpea plants [12] [19] [23]. In this connection, the results in this study showed that kinetin application had the most effective growth regulator for improving yield and yield components of cowpea plants as comparing to other growth regulators used. These findings are supported by the results of El-Saeid et al. (2010) [21] who reported that IAA increased growth parameters of cowpea plants. Moreover, Choudhury et al. (2013) [4] stated that enhanced tomato yield by IAA and $\mathrm{GA}_{3}$ may be mediated through changes in the activities of carbohydrate metabolism enzymes.

Growth regulators used in this study significantly increased total soluble sugars in the yielded cowpea seeds. These results are supported by the results of 
Khandaker et al. (2018) who stated that flower injection of IAA at 30 and 90 $\mathrm{mg} / \mathrm{L}$ increased total soluble sugars of Abelmoschus esculentus. Furthermore, Kinetin application significantly increased soluble carbohydrates content and acid invertase activity [16] [17]. In addition, Prajapati et al. (2015) [12] found an excessive accumulation of starch of Lemna minor as a result of kinetin treatment.

From this study, it is clear that application of growth regulators significantly increased the protein content of developing cowpea seeds. IAA was reported by several investigators to cause an increase in protein and other nitrogenous compounds in several plant species [12] [16] [19]. Recently, Khandaker et al. (2018) [7] stated that externally applied $50 \mathrm{ppm}$ IAA as a foliar spray on maize, bean and cowpea shoot led to an increase in total nitrogen content, mainly protein. Also, it was found that application of $\mathrm{GA}_{3}$ significantly increased protein content in yielded cowpea seeds. The findings of [2] [4] support these results. Furthermore, kinetin appeared to the most effective hormone in protein manipulation with in developing seeds of cowpea plants [3] [12] [21] [23]. The obvious increase in protein content of seeds as a result of kinetin application may be due to the fact that kinetin increased the chlorophyll content, stomatal conductance and enhanced the accumulation of dry matter within the developing seeds [7] [21], and this may be explained on the fact that kinetin enhances mobilization center thus directing the migration of substances and their accumulation into the developing seeds.

It is clear from the present study that application of IAA increased endogenous auxins and gibberellins activities in the cowpea seeds. Similar effects was observed by Prajapati et al. (2015) who found that foliar application of IAA induced the up-regulated expression of gibberellin biosynthesis gene and produced more about polysaccharides so that growth may continue for longer periods. Furthermore, IAA initiates a signal transduction pathway resulting in production of secondary messengers that activate pre-existing $\mathrm{H}^{+}$-ATPases and stimulates the expression of several gens related to growth and development [7] [16] [17]. Seed presoaking in $\mathrm{GA}_{3}$ at different concentrations caused a significant increases in the level of endogenous auxins, gibberellins and cytokinins, meantime. A reduction in abscisic acid level was observed. These results are supported by El-Saeid et al. (2010) [21] who stated that $\mathrm{GA}_{3}$ may induce proteolytic enzymes formation that could be expected to release tryptophan, a precursor of IAA.

Kinetin application resulted in a significant increase in auxins, gibberellins and cytokinins of cowpea seeds. Such increase might have resulted from induction of influx of certain metabolites particularly sugars into seeds [17]. This was followed by an increase in osmotic uptake of water and consequently the sharp rise of fresh weight of the seed which followed by an increase in extractable gibberellin activity of the seed. Moreover, a noticeable increase in cytokinin content of yielded seeds of cowpea plants as a result of kinetin treatment. These results might to due to increase in seed division and consequently a high amount of cytokinins in yielded seeds [19] [28]. 
From the present obtained results, it can be concluded that seed presoaking with different concentrations of IAA, $\mathrm{GA}_{3}$ or kinetin increased yield quality of cowpea plants by inducing a remarkable increase in yield components as well as increases in protein content and total soluble sugars in yielded seeds. Also, it is evident from this study that kinetin application appeared to be the most effective hormone for improving productivity and endogenous auxins, gibberellin and cytokinin of cowpea plants. Further studies will be needed to investigate the effect of growth bio-regulators on some different metabolic pathways, molecular analysis and different enzymes in cowpea plants.

\section{Conflicts of Interest}

The author declares no conflicts of interest regarding the publication of this paper.

\section{References}

[1] Langyintuo, A.S., Lowenberg-DeBoer, J., Faye, M., Lambert, D., Ibro, G., Moussa, B., Kergna, A., Kushwaha, S., Musa, S. and Ntoukam, G. (2003) Cowpea Supply and Demand in West and Central Africa. Field Crop Research, 82, 215-231.

https://doi.org/10.1016/S0378-4290(03)00039-X

[2] Ayyub, C.M., Manan, A., Pervez, M.A., Ashraf, M.I., Afzal, M., Ahmed, S. and Shaheen, M. (2013) Foliar Feeding with Gibberellic Acid Staratgy for Enhanced Growth and Yield of Okra (Abelmoschus esculentus). African Journal of Agricultural Research, 8, 3299-3302.

[3] Al-Humaid, A.T. (2000) The Influence of Foliar Nutrition and Gibberellic Acid Application on the Growth and Flowering of Sntrixrase Plants. Alexandria Journal of Agricultural Research, 46, 83-90.

[4] Choudhury, S., Islam, N., Sarkar, M. and Ali, M. (2013) Growth and Yield of Summer Tomato as Influenced by Plant Growth Regulators. International Journal of Sustainable Agriculture, 5, 25-28.

[5] Rabie, K.A., Shehata, S.A. and Bondok, M.A. (1996) Hormone Balance, Germination, Growth and Pod Shedding of Faba Bean as Affected by Gamma Irradiation. Annals of Agricultural Sciences, 41, 551-566.

[6] Aldesuquy, H.S. (2000) Effect of Indol-3-yl Acetic Acid on Photosynthetic Characteristics of Wheat Flag Leaf during Grain Filling. Photosynthetica, 38, 135-141. https://doi.org/10.1023/A:1026712428094

[7] Khandaker, M.M., Azam, H.M., Rosnah, J., Tahir, D. and Nashriyah, M. (2018) The Effects of Application of Exogenous IAA and $\mathrm{GA}_{3}$ on the Physiological Activities and Quality of Abelmoschus esculentus (Okra) var. Singa 979. Journal of Tropical Agricultural Science, 41, 209-224.

[8] Kordei, B. and kutschera, V. (1998) Re-Examination of the Solute-Import Hypothesis of Gibberellins Action in Developing Action in Developing Pea Internodes. Journal of Plant Physiology, 135, 693-699. https://doi.org/10.1016/S0176-1617(98)80222-8

[9] Shawkat, E.M. (2000) Ecophysiological Studies on the Adaptation of Gossypium arboretum L. in Egypt. Ph.D. Thesis, Mansoura University, Mansoura.

[10] Abdel-El-Fatah, M.A. (1997) Effect of Phosphorus, Boron, GA $_{3}$ and Their Interac- 
tion on Growth, Flowering, Pod Setting, Abscission and Both Green Pod and Seed Yields of Broad Bean Plants. Alexandria Journal of Agricultural Research, 42, 311-332.

[11] Farghali, M.A. and Hussein, H.A. (1994) Soaking Carrot Roots in Growth Regulators Solutions to Improve Seed Production. Assiut Journal of Agricultural Sciences, 25, 89-97.

[12] Pradapati, S., Jankar, T., Singh, O., Raypariya, N., mandloi, R. and Jain, P. (2015) Plant Growth Regulators in Vegitable Production: An Overview. Plant Archives. 15, 619-626.

[13] Sontakey, P.Y., Belsare, W.V., Deotale, R.D., Takzure, S.C. and Wankhede, S.Z. (1991) Relative Influence of Growth Hormones on Growth and Yield Performance of Seswamum (Sesamumindicum L.). New Agriculture Journal, 1, 206-208.

[14] Bandok, M.A., Rabie, K.A. and El-Antably, H.M. (1991) Effect of Foliar Application of Some Growth Regulators on Endogenous Growth Hormone Levels of Cotton Plants. Annals of Agricultural Sciences, 36, 31-41.

[15] Abo-Hamed, S.A., Mansour, F.A. and Aldesuquy, H.S. (1987) Shoot Growth and Morphological Characteristics of Wheat as Influenced by Sodium Salicylate, Alar, Asalam and Kinetin. Mansoura Science Bulletin, Egypt, 14, 203-221.

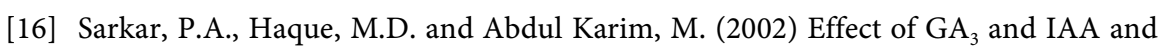
Their Frequency of Application on Morphology, Yield Contributing Characters and Yield of Soybean. Journal of Agronomy, 1, 119-122. https://doi.org/10.3923/ja.2002.119.122

[17] Shah, S.H. (2011) Comparative Effects of 4-Cl-IAA and Kinetin on Photosynthesis, Nitrogen Metabolism and Yield of Black Cumin (Nigella sativa L.). Acta Boutinca Croatica, 70, 91-97. https://doi.org/10.2478/v10184-010-0008-3

[18] Sharif, R. and Dale, J.E. (1980) Growth Regulating Substances and the Growth of Tiller Buds in Barley: Effect of Cytokinins. Journal of Experimental Botany, 31, 932-930.

[19] Vamil, R., Haq, A. and Agnihotri, R. (2010) Plant Growth Regulators as Effective Tool for Germination and Seedling Growth for Bambusaar undinaccae. The Journal of Agricultural Science, 1, 233-236.

[20] Khfaga, E.R., Arafa, A.A. and Abed, A.M. (1990) Effect of Kinetin and IAA on Growth and Yield of Cassava Plants Derived from Previously Stored Stem Cuttings. Journal Agriculture Science, Mansoura University, 15, 1420-1439.

[21] El-Saeid, H.M., Abou, S.D. and El-Tohamy, W.A. (2010) Growth Characters, Yield and Endogenous Hormones of Cowpea Plants in Response to IAA Application. Research Journal of Agriculture and Biological Science, 6, 27-31.

[22] Reena, T., Deotale, R.D., Neeta, A. and Chore, C.N. (1999) Influence of Seed Soaking in IAA and Kinetin Solutions on Growth and Yield of Soybean. Journal of Soils \& Crops, 9, 72-74.

[23] Guo, W.M. and Shang, A.W. (1999) Regulation of Endogenous Hormones on Abscission Sencsena of Mei Flowers (Prunu smunu) Journal of Beijing Forestry University, 21, 42-48.

[24] Beadle, C.L. (1993) Growth Analysis. In: Hall, D.C., Scurlock, J.M., Bolhar-Norden, H.R., Lee-Good, R.C. and Long, S.P., Eds., Photosynthesis and Production in a Changing Environment. A Field and Laboratory Manual, Chapman and Hall, London, 36-46. 
[25] Abdel-Fattah, G.M., Fatma, F.M. and Ibrahim, A.H. (2002) Interactive Effects of Endomycorrhizal Fungus Glomus etunicatum and Phosphorus Fertilization on Growth and Metabolic Activities of Broad Bean Plants under Drought Stress Conditions. Pakistan Journal of Biological Sciences, 5, 835-841.

https://doi.org/10.3923/pjbs.2002.835.841

[26] Bradford, M.M. (1976) A Rapid and Sensitive Method for the Quantification of Microgram Quantities of Protein Utilizing the Principle of Protein-Dye Binding. Analytical Biochemistry, 72, 248-254. https://doi.org/10.1016/0003-2697(76)90527-3

[27] Terry, P.H., Louis, H.A. and Heriagh, E.A. (1982) Identification of Abscisic Acid in Tulipages nerianta L. by Gas Liquied Chromatography with Electron Capture and Combined Gas. Liquid Chromatography and Mass Spectrometery. Plant Physiology, 70, 1574-1579. https://doi.org/10.1104/pp.70.5.1574

[28] Van-Staden, J. (1983) Cytokinins, Seed Development and Germination. South African Journal of Botany, 19, 825-831. 